\title{
Is Information Technology Leveraged Strategically in Slovene Small Firms?
}

\author{
Dušan Lesjak \\ University of Maribor, Faculty of Economics and Business, Maribor, Slovenia
}

\begin{abstract}
The extent to which information technology (IT) is used strategically is measured on a sample of 147 small Slovene firms. Slovenia is interesting from a small business perspective, because since 1990, when the transformation of its economy started, the number of small business has increased almost 6 times (from almost 6.500 to nearly 35.000 in 1999). The results have shown IT industry leadership and also IT's role in a firm to be the strongest predictors in the strategic usage of IT.
\end{abstract}

Keywords: information technology, strategic IT usage, small firms, Slovenia

\section{Introduction}

\subsection{General Background}

A belief commonly held in the popular literature is that information technology (IT) plays an increasingly critical role in the design and implementation of organizational strategy. IT has been described as facilitating the competitiveness, organizational transformation, increased market share, and heightened customer service (Callon 1996, Kettinger et al. 1994, Neumann 1994). Since IT provides information and communication channels among the various participants, many assume that adoption of IT must alter the basis for industry competition (Bhide 1994, Peppard 1993, Porter and Miller 1985).

Indeed, case studies support the idea that IT helps firms in developing and implementing strategy, and yields direct economic benefit (Baura et al. 1995, Taylor and Todd 1995). Increasingly affordable computers and software make strategizing with IT tools accessible to many small- and medium-size enterprises (SMEs) (Baker and Baker 1996). Yet, previous studies suggest that up to two-thirds of
SMEs relegate IT to performing routine operations only (Dutta and Evrard 1999, Moreton 1995, Langley and Traux 1994) rather than leveraging it to help advance the firm' strategy (Rue and Ibrahim 1995, Lesjak 1993).

There is a sizeable body of literature examining IT diffusion (Moore and Benbasat 1991, Grover 1993), the growth of IT adoption and IS planning in firms (Doukidis et al 1994, Teo and Ank 1999, Bergeron et al 1998), and the increasing proficiency or literacy of IT users (Rainer and Harrison 1995, Fink 1998). Few of these research streams, however, directly address the strategic use of IT, which is where much of the theoretic potency of IT application lies.

The research discussed below introduces IT use in developing economies.

\subsection{Other Studies of IT Development in Developing Economies}

The relationship between IT investment and business performance in various countries has only recently been investigated in less developed business environments. These findings are not in concert with the common understanding of the use of IT in strategy found in the studies conducted in industrialized nations.

Serafeimidis and Doukidis (1999) used the case study approach to investigate the impact of IT investment on business performance in Greece. They concluded that in their sample, IT investments could not be related to business financial success. They argue that part of the reason IT did not impact financial success in their sample 
was because managers did not have the education to make the best use of strategic information systems.

Tam (1998) had a similar finding. He examined the impact of IT investment on firm performance in four newly industrialized economies (Hong Kong, Singapore, Malaysia, and Taiwan). His findings replicate those studies in the US, finding no relationship between IT expenditures in large firms and stock market return. Tam did not directly study IT use in strategy.

Doukidis, Smithson, and Lybereas (1994) demonstrated the value of conducting repeated measurements over time. They report on a fiveyear follow-up of their earlier study of small business use of IT in Greece. One of their conclusions was that Greek small businesses do not follow the maturational stages seen in other studies (Asian. . . 1994, Cooper and Zmud 1990).

\subsection{Slovenia's Economic Transformation}

Although small, Slovenia leads many Central and Eastern European (CEE) transitional economies in economic growth and productivity. Slovenia's small firms have played an important role in this transition. The number of Slovene small firms has increased six fold since 1990, when the transformation of Slovenia's economy began. In 1999, Slovenia had around 34,500 small businesses (almost all new businesses), compared to 887 large and fewer than 2,143 midsize firms (Ministry... 2000). Figure 1 shows this pattern of growth.

Structural differences between Slovenia's small firms' sectors and those of Western Europe, as well as year-to-year indicators, suggest that transition is still taking place among small firms. For example, although there is a fair amount of variability in the employment share of small firms in Western Europe (ranging from Spain's high of $81.1 \%$ down to Belgium's low of $56.2 \%$ (Eurostat 1999) - they are considerably higher than Slovenia's 24\% (Ministry... 2000). The sectors represented by small firms differ as well. For example, although only $10 \%$ of Western Europe's new small firms have been in the area of manufacturing and construction, these sectors constitute $42 \%$ of new small firms in Slovenia (Ministry...2000). Slovene small business is likely to grow increasingly significant since they are growing in number, spawning both new jobs and economic growth.

As small firms jockey for positions of leadership in their respective industries, IT offers a possible advantage for the growing small firms in terms of support for higher quality, lower costs, product innovation, better customer relationship, etc. The question is, is IT being leveraged to that end?

\section{A Model of Intra-Firm Strategic IT Usage}

Based on existing literature (Cragg and King 1993, Grover 1993, Bergeron et al 1998), a theoretical model and two accompanying hypotheses can be generated regarding possible influences and outcomes of strategic IT usage in small firms. We focus on two intra-firm characteristics in particular-the linkage of strategy and IT, and the firm's IT experience and investment.

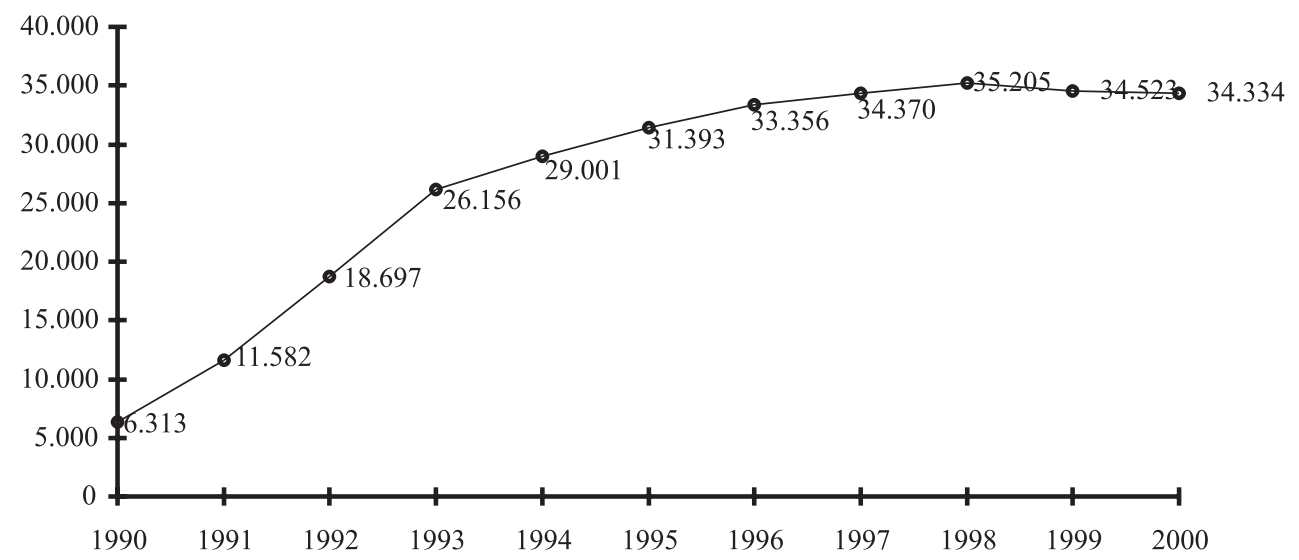

Fig. 1. Number of Small Firms in Slovenia. 




Fig. 2. An Intra-Firm model of Strategic IT usage.

To test the framework in the context of Slovenia small business, we put forward two main hypotheses.

\subsection{Strategy-IT Linkage}

If managers view IT as an expense rather than an investment, they likely will see its impact in affecting strategy-or in paying ongoing dividends for the firm-as low. Second, IT may be perceived by managers on a continuum from being largely irrelevant or being integral to a firm's strategy. If IT is not viewed as potentially facilitating the formation, evaluation, or implementation of firm strategy, it is unlikely that IT will be leveraged strategically (Wiseman 1994). Following this reasoning, we hypothesize that:

H1: IT will be leveraged strategically in firms where:

a) IT is viewed as a strategic investment, and;

b) IT's role is perceived as being integral to strategy.

\subsection{IT Experience}

Small firms historically have lagged behind large firms in innovation and the adoption of IT. Additionally, research in IT use and diffusion suggests that experience may affect the strategic utilization of IT. Thus, our second hypothesis is:

$\mathrm{H}$ 2: IT will be leveraged strategically and profitably:

a) longer a firm has used IT

b) higher the percentage of IT users in a firm

c) more IT experts there are among employees, and

d) more a firm is viewed as an IT leader in its industry.

\section{Sample}

In this study, the criteria for defining a small business were adopted from the Agency for Payment System (APS) (1998). A small business is one that satisfies at least $t w o$ of the following - It has 50 or fewer employees, fixed assets of 0.5 million Euro or less, and annual sales of 1 million Euro or less.

To further focus the sample we employed two additional criteria. We selected firms with an annual revenue of more than 0.1 million Euro to exclude firms which probably cannot afford IT, and 10 or more employees to exclude micro firms.

The names and the addresses of small businesses that fulfilled the above criteria were obtained from the APS. Nonprofit organizations, publicly-owned businesses, and wholly-owned subsidiaries of large businesses were excluded from the survey sample frame, leaving a sample of 974 businesses or 2.82 percent of all small business in Slovenia.

Surveys were sent to all 974 small firms. Of these, 161 surveys were returned, giving a response rate of 16.5 percent. Responses from 14 businesses were discarded because they had incomplete data, resulting in a final sample of 147 usable questionnaires (15.1 percent).

To assure that the respondents were similar in characteristics to the sample frame, these final 147 firms were compared to the 974 in terms of the number of employees, income, and income per employee. (Data on all firms were obtained from the APS.) T-tests showed no significant differences on any of these measures (income: $t=0.65 ; p=0.52$; employees: $t=0.30$; $p=0.76$; income per employee: $t=0.72$; $p=0.47)$. 


\begin{tabular}{||l|l|r|r||}
\hline \hline Characteristic & Choices & Frequency & Percent \\
\hline \hline Sector & Manufacturing & 68 & 46.3 \\
& Trade & 42 & 28.6 \\
& Business Services & 26 & 17.6 \\
& Construction & 11 & 7.5 \\
\hline Years in business & $>7$ years & 25 & 17.0 \\
& 7 and $<7$ & 122 & 83.0 \\
\hline Operating at a profit or loss & Profit & 127 & 86.4 \\
& Breakeven & 1 & .7 \\
Number of full-time equivalent & Loss & 19 & 12.9 \\
employees & $10-20$ & 80 & 54.8 \\
& $21-30$ & 22 & 15.1 \\
& $31-40$ & 16 & 10.9 \\
& $41-50$ & 13 & 8.9 \\
& $51-$ & 16 & 10.3 \\
\hline Profit-loss/employees & & 17 & 11.6 \\
& $5,001-10,000$ & 43 & 29.2 \\
& $10,001-20,000$ & 49 & 33.3 \\
& $20,001-30,000$ & 21 & 14.3 \\
& $30,001-$ & 17 & 11.6 \\
\hline Computer usage in the firm & $>7$ years & 44 & 29.9 \\
& $6-7$ & 27 & 18.4 \\
& $4-5$ & 43 & 29.3 \\
& $<4$ & 33 & 22.4 \\
\hline Employees, who are IT users & $86 \%-100 \%$ & 40 & 27.2 \\
& $41 \%-85 \%$ & 33 & 22.4 \\
& $11 \%-40 \%$ & 38 & 25.9 \\
& $0 \%-10 \%$ & 36 & 24.5 \\
\hline & $15 \%-100 \%$ & 35 & 23.8 \\
& $6 \%-14 \%$ & 35 & 23.8 \\
& $1 \%-5 \%$ & 31.3 \\
& $0 \%$ & 21.1 \\
\hline
\end{tabular}

Table 1. Characteristics of the Sample.

Table 1 presents the sample characteristics. On average, small businesses in the sample had 29 employees and mean annual sales per employee of 101,922 Euro. The average firm had 5.8 years of computer experience, and on average, about $50 \%$ of the firms' employees were computer literate. In $31(21.1 \%)$ firms there was no one responsible for IT.

\section{Measures/Variables}

\subsection{Grouping Variables}

The firms of all respondents fell within one of four categories: Manufacturing $(n=68)$, trade (import-export) $(\mathrm{n}=42)$, business services (accounting, consulting, etc.) $(\mathrm{n}=26)$, and construction $(n=11)$. The last group was not split out for separate analyses due to its small size.

\subsection{Independent Variables}

Strategy-IT Linkage - To test the link between IT and strategy, respondents were asked to answer two questions - one on whether expenditures for IT were viewed as expenses or investments, and the other which asked respondents to indicate whether IT was viewed as integral to strategy or merely supportive of operations. 
IT Experience - Respondents were asked in four questions how many years they had used IT, the percentage of employee IT experts, the percentage of employee IT users, and their view on whether the firm was an IT industry leader or laggard. The overall role of IT was adapted from Grover (1993). Other items were generated for the present study.

\subsection{Dependent Variables}

Strategy - Strategy is measured by 11 -item measures using scales (from 1 to 7; used for almost all similar variables) developed by Covin et al. (1994) and Kim and Choi (1994).

IT Usage - This study uses 8-item measures of IT strategic usage. It is an enhancement of the 6-item measures developed by Cragg and King (1993).

Strategy-IT Usage - We asked respondents to identify the degree to which they use IT to perform different functions. This list of functions could then be compared across different strategies and industries as explained in the section below.

Financial performance - Respondents were asked to evaluate their relative standing on financial performance as compared with their competitors. This was used rather than absolute financial measures to avoid complications of inter-industry differences, government factors, and market conditions. Financial performance was measured by an 11-item scale that includes traditional economic measures such as sales, revenue, profit, etc. We asked respondents to indicate the importance of a set of financial measures in their firm and the degree of satisfaction with firm performance on these outcomes.

\section{Results and Discussion}

\subsection{Correlations among Independent Variables}

Correlations among the Strategy-IT Linkage variables and the IT Experience variables (Table 2) suggest that firms with a high percentage of IT users also tended to have a relatively large percentage of IT experts. Additionally, firms perceived as being in a role of IT leadership tended to be IT users for a longer time, have a lot of IT users and viewed IT as an investment rather than an expense.

\subsection{Strategic IT Usage and Financial Performance by Economic Sectors}

Strategic IT Usage score (a dependent variable) - To identify the strategic use of IT in various firms in similar sectors, we began by performing a principle components analysis (Varimax with Kaiser Normalization method) on various IT applications - such as in research and development, finance and accounting - to identify the IT applications that fit together for a sector of the economy.

Since we weren't satisfied with the percentage of the explained variance of the first component for the research variable "Firm IT usage" $(37.3 \%)$ and since factor analysis revealed more than one underlying dimension for a construct, the factors were further examined. An eigenvalue of 0.9 or above was used as a criterion to

\begin{tabular}{llllllll}
\hline \hline Questions & Mean & \multicolumn{1}{c}{ s.d. } & 9 & 10 & 11 & 13 & 15 \\
\hline \hline 9. Years using IT & 2.44 & 1.14 & & & & & \\
10. Employee IT Experts & 2.50 & 1.07 & .08 & & & & \\
11. Employee IT Users & 2.48 & 1.14 & .12 & $\mathbf{. 3 5}^{* *}$ & & & \\
13. IT Investment Attitude & 1.61 & .53 & .06 & .11 & .14 & & \\
15. IT Industry Leadership & 2.57 & .82 & $\mathbf{. 1 8}$ & .02 &. $\mathbf{2 1} 1^{* *}$ & $.288^{* *}$ & \\
16. IT Company Role & 1.89 & .89 & -.03 & .11 & .02 & .01 & .00 \\
\hline \hline
\end{tabular}

Significant correlations are in boldface: ${ }^{*} p \leq .05 ;{ }^{* *} p \leq .01$

Table 2. Intercorrelations among Strategy-IT and IT Experience variables. 


\begin{tabular}{lrrr}
\hline \hline Firm IT Usage: & $\begin{array}{c}\text { Factor 1 } \\
\text { Manufacturing }\end{array}$ & $\begin{array}{c}\text { Factor 2 } \\
\text { Trade }\end{array}$ & $\begin{array}{c}\text { Factor 3 } \\
\text { Business Services }\end{array}$ \\
\hline \hline Research and development & $\mathbf{. 9 2}$ & & \\
Purchasing/Procurement & .35 & .35 & .29 \\
Production & $\mathbf{. 7 2}$ & .32 & -.10 \\
Marketing and Sales & .20 & $\mathbf{. 8 5}$ & .21 \\
Inventory (warehousing) & & & .22 \\
Transport & & $\mathbf{. 8 0}$ & $\mathbf{. 8 1}$ \\
Personnel/Human Resources & .28 & .11 & $\mathbf{. 8 5}$ \\
Finance and Accounting & & & .94 \\
Eigenvalue & 2.98 & 1.41 & 11.71 \\
\% of common variance explained & 37.29 & 17.58 & 66.59 \\
Cumulat. \% of variance explained & 37.29 & 54.88 & \\
\hline \hline
\end{tabular}

$n=147$, Factors in boldface have significant factor loadings $\geq .70$.

Table 3. Principle Component Analysis for Firm IT Usage.

estimate the number of factors underlying the construct. Because the construct had 3 interpretable dimensions (which altogether explain $66.6 \%$ of the variance), reliability was computed for each dimension.

Table 3 shows that 3 factors emerged which we labeled as follows:

- Factor 1: Manufacturing - because research and development and production functions have high coefficients

- Factor 2: Trade - because marketing and sales and transportation functions have high coefficients, and

- Factor 3: Business services - because personnel and human resources and finance/ accounting have high coefficients in contrast with marketing/sales.

Next, we reasoned that firms in manufacturing, trade, and business services which are using IT strategically, will score high in the use of items under the factor items which matched their respective industry. To determine whether this is the case, respondents were separated into four groups according to industry (respondents only indicated four industries-manufacturing, trade, business services, and construction).

For those who identified their firms as "manufacturing", the weight for each factor item in Table 3 was multiplied by each respondent's estimate of his/her firm's particular use of that form of IT. In other words, manufacturing firm
X's utilization of IT in research and development was multiplied by .92 (Table 3, manufacturing column, line 1); its purchasing and procurement usage was multiplied by .35 , and so on. Responses to all the factor items for manufacturing firms were summed to produce a dependent variable measure of strategic IT applications. The same procedure was completed for trade and business service firms. We did not test the construction firms due to their small sample size and because a factor analysis of IT applications did not produce a corresponding factor. In each industry, the higher the strategic IT usage score, the more IT usage coincided with elements common to that particular economic sector.

Since the variable "overall financial performance" correlated significantly with most of the other financial performance indicators, we decided to use it as the sole dependent variable measure of financial performance.

We attempted to predict these two dependent measures - strategic usage and financial performance - in stepwise multiple regression equations. For all three economic sectors, one to three factors out of six successfully predicted actual strategic IT use and financial performance (see Table 4). The strongest predictor was IT Industry Leadership (the perception that the firm was an industry leader in utilizing IT), suggesting that managers accurately assessed their firm's relative position of IT application and that of their competitors as well. 


\begin{tabular}{|c|c|c|c|c|c|c|c|c|}
\hline \multirow{3}{*}{ Step Independent Variable } & \multicolumn{8}{|c|}{ Dependent Variable } \\
\hline & \multicolumn{4}{|c|}{ Strategic IT Use } & \multicolumn{4}{|c|}{ Financial Performance } \\
\hline & Adj. $R^{2}$ & $\beta$ & $t$ & $F$ & Adj. $R^{2}$ & $\beta$ & $t$ & $F$ \\
\hline Manufacturing Firms $(n=68)$ & & & & $\overline{9} 9.52^{* * *}$ & & & & $4.26^{*}$ \\
\hline 1 IT Industry Leadership & .06 & .25 & $10.17^{* * *}$ & & .05 & -.2 & $-2.06^{*}$ & \\
\hline 2 IT Company Role & .11 & .25 & $10.27^{* * *}$ & & & & & \\
\hline Trade Firms $(n=42)$ & & & & $8.35^{* * *}$ & & & & $7.95^{* *}$ \\
\hline 1 IT Industry Leadership & .08 & .26 & $7.24^{* *}$ & & .15 & .41 & $-2.82^{*}$ & \\
\hline 2 Years Using IT & 11 & -.19 & $-3.19^{*}$ & & & & & \\
\hline 3 IT Company Role & .14 & .17 & $2.35^{*}$ & & & & & \\
\hline Business Service Firms $(n=26)$ & & & & $9.00^{* *}$ & & & & $4.78^{*}$ \\
\hline 1 IT Industry Leadership & .06 & -.25 & $-3.00^{* *}$ & & .14 & -.4 & $-2.19^{*}$ & \\
\hline
\end{tabular}

${ }^{*} p<.05 ;{ }^{* *} p<.01 ;{ }^{* * *} p<.001$

Table 4. Regression Results for Strategic IT Usage in Manufacturing, Trade, and Business Services.

The view of IT's relative contribution to firm strategy was predictive in manufacturing and trade firms, and the length of time that a firm utilized IT was predictive for trade firms. Other measures of IT diffusion and experience did not correlate with strategic IT usage.

\section{Conclusion}

The results suggest that Slovene small firms indeed are using some applications of IT strategically and that strategic IT usage is associated with two or three factors. The hypothesis addressing strategy-IT linkage (H1) was partially supported. Viewing IT as a strategic investment (H1a) did not significantly contribute to strategic IT usage. But the perception of IT's link to strategy did make a difference-when IT was perceived as being integral to a firm's strategy (H1b), it contributed to strategic IT usage in manufacturing and trade firms. Neither viewing IT as a strategic investment nor perceiving IT as integral to strategy significantly related to the financial performance of the sample firms.

The second hypothesis addressed the link between IT experience and strategic and profitable IT usage. Here again, partial support was found. The percentage of IT users $(\mathrm{H} 2 \mathrm{~b})$ and experts $(\mathrm{H} 2 \mathrm{c})$ in the firm had no significant influence on whether IT was strategically or profitably utilized. The length of time IT had been used in a firm $(\mathrm{H} 2 \mathrm{a})$ was a significant contributor among trade firms but not among manufacturing or business service firms. Whether a firm was viewed as an IT leader (H2d) in its industry was the strongest predictor of strategic and profitable IT usage. This was true among manufacturing, trade, and business service firms.

The findings can help small business narrow the gap regarding productivity and profitability between Slovenia and the European Union, in terms of competitive strategy and business areas in which IT usage could be used strategically. We note the following:

- In the near future, an additional $20 \%$ will be employed in the business sector and they will need additional IT (Eurostat 1999). This means that there will be a greater need for managers who understand how to use IT for strategic advantage.

- In more developed markets, business services firms are very strong IT users. This is not yet the case in Slovenia. This will change as small business in Slovenia matures.

- Global trends, such as usage of the Internet, e-commerce, and networked cooperation among firms, will have a big impact on small Slovene firms in near future. These 
changes definitely impact their attitude to IT and its usage.

Weaknesses of the present study include the following:

- First, we assumed that the common utilization of IT applications in economic sectors was an indicator of areas of strategic importance.

- There is some multicollinearity present across the variables. Additionally, environmental variables (e.g., the degree of rivalry, the number of competitors, etc.) might be tested in further research, as well as the reasons why small firms' managers/owners do and do not utilize IT strategically.

- Last, managers' opinions of IT strategic applications can deviate from actual usage. This is especially so in the rapidly changing environments such as that of Slovenia.

In the next stage of this research, data will be collected and analyzed every two years to detect changes in the strategic use of IT in small Slovene firms. Future studies will be designed to enable additional appropriate analysis, such as structural equation modelling, to explore the underlying causes and effects of this complex situation.

\section{References}

[1] AGENCY FOR PAYMENT SYSTEM OF SLOVENIA, Bulletin on the Business Results within the Economy of Slovenia, Agency for Payment System of Slovenia, Ljubljana, 1998.

[2] ASIAN PRODUCTIVITY ORGANIZATION, Report on Conclusions and Recommendations, Symposium on Applications of Information Technology in National Development, November, 1994.

[3] K. BAKER, S. BAKER The 1996 Business Strategist's Software Dictionary, Journal of Business Strategy, 17(1) (1996), 41-52.

[4] A. BAURA, C.H. KRIEBEL, AND T. MuKHOPADHYAY, Information Technologies and Business Value: An Analytic and Empirical Investigation, Information Systems Research, 6 (1995), 3-23.

[5] F. Bergeron, L. RAYMOND, M. Gladu, AND C. LECLERC, The contribution of information technology to the performance of SMEs: "alignment of critical dimensions", $6^{\text {th }}$ ECIS Proceedings, Volume 1 (1998), 173-187.
[6] J. BHIDE, How Entrepreneurs Craft Strategies that Work, Harvard Business Review (1994), MarchApril, 150-161.

[7] J. CALlon, Competitive Advantage through Information Technology, New York, McGraw-Hill, 1996.

[8] E. G. CARMines, R. A. Zeller, Reliability and Validity Assessment, Sage, Beverly Hills, CA, 1981.

[9] R. B. COOPER, R. W. ZMUD, Information Technology Implementation Research: A Technological Diffusion Approach, Management Science 36:2 (1990), 123-139.

[10] J. P. Covin, D. P. Slevin, R. L. ShultZ, Implementing Strategic Mission: Effective Strategic, Structural and Tactical Choices, Journal of Management Studies, 31 (1994), 481-504.

[11] P. B. CRAGG, M. KING, Small-Firm Computing: Motivators and Inhibitors, MIS Quarterly, (1993), March, 47-60.

[12] G. I. DoukIDIS, S. SMITHSON, T. LYBEREAS, Trends in Information Technology in Small Businesses, Journal of End User Computing, 6:4 (1994), 1525.

[13] S. DUTTA, P. EVRARD, Information Technology and Organization within European Small Enterprises, European Management Journal, 17(3), (1999) 239_ 251.

[14] Eurostat, Enterprises in Europe, SME Database Data, 1990-1995, Luxembourg, 1999.

[15] D. FINK, Guidelines for the Successful Adoption of Information Technology in Small and Medium Enterprises, International Journal of Information Management, 18(4), (1998), 243-253.

[16] V. Grover, An Empirically Derived Model for the Adoption of Customer-based Interorganizational Systems, Decision Sciences, 24(3), (1993), 603640.

[17] M. IgBaria, N. Zinatelli, A. L. M. CAVAYe, Analysis of Information Technology Success in Small Firms in New Zealand, International Journal of Information Management, 18(2), (1998), 103-119.

[18] W. Kettinger, V. Grover, S. Guha, A. Segars, Strategic Information Systems revised: A Study in Sustainability and Performance, MIS Quarterly, March, (1994).

[19] Y. KIM, Y. CHOI, Strategic Types and Performances of Small Firms in Korea, International Small Business Journal, 13(1), 1994, pp. 13-25.

[20] A. Langley, J. TrauX, A Process Study of New Technology Adoption in Smaller Manufacturing Firms, Journal of Management Studies, 31, (1994), 621-652.

[21] D. LESJAK, Evaluating (Current and Future) Impacts of Information Technology Usage, Advances in Management, Windsor, Ontario, Canada, The International Institute for Advanced Studies in Systems Research and Cybernetics, (1993), 143-148. 
[22] MINISTRY OF SMALL BUSINESS AND TOURISM, Small Business in Slovenia, Ministry of Small Business and Tourism, Ljubljana, 2000.

[23] G. C. Moore, I. Benbasat, Development of an Instrument to Measure the Perceptions of Adopting an Information Technology Innovation, Information Systems Research, 2(3), (1991), 192-222.

[24] R. MORETON, Transforming the Organization: The Contribution of the IS Function, Journal of Strategic Information Systems, 4, (1995), 149-163.

[25] S. NeUmAnN, Strategic Information Systems: Competition through Information Technologies, New York; Macmillan College Publishing Co., 1994.

[26] J. PEPPARD, Using IS/IT to Gain Competitive Advantage. In Peppard, J. (ed.), I.T. Strategy for Business, Pitman Publishing, London, 1993.

[27] M. E. PORTER, V. E. Miller, How Information Gives You a Competitive Advantage, Harvard Business Review, 4, (1985), 149-160.

[28] R. K. JR. RAINER, A. W. HARrison, Toward Development of the EUC Construct in a University Setting, Decision Sciences, 24(26), (1995), 11871201.

[29] L. W. RuE, N. A. IBRAHIM, The Status of Planning in Smaller Family-Owned Business, Family Business Review, 9(1), (1995), 29-43.

[30] V. SERAFEIMIDIS, G. I. DOUKIDIS, Management of Information Technology Investments in Less Developed Environments: Experiences from Greece, Journal of Global Information Technology Management 2:4, (1999), 4-22.

[31] K. Y. TAM, The Impact of Information Technology Investments on Firm Performance and Evaluation: Evidence from Newly Industrialized Economies, Information Systems Research, 9:1, (1998), 85-98.

[32] S. TAYLOR, P. A. TODD, Understanding Information Technology Usage: A Test of Competing Models, Information Systems Research, 6, (1995), 144-152.

[33] T. S. H. TEO, J. S. K. ANG, Critical Success Factors in the Alignment of IS Plans with Business Plans, International Journal of Information Management, 19(2), (1999), 173-185.

[34] C. Wiseman Foreword, Strategic Information Systems: A European Perspective, Chichester, (C. Ciborra, T. Jelassi, Ed), (1994), John Wiley, UK.

Received: July, 2000 Revised: April, 2001 Accepted: May, 2001

Contact address Dušan Lesjak University of Maribor Faculty of Economics and Business, Razlagova 20, 2000 Maribor, Slovenia Phone: +38622290243 Fax: +38622516681 e-mail: dusan.lesjak@uni-mb.si http:/www. uni-mb.si/ $\operatorname{epflesja/~}$
DUŠAN LESJAK is a Professor of MIS and an Executive Director of Management and MIS Institute at Faculty of Economics and Business, University of Maribor. His research interest includes strategic and management information systems, information resource management in small business and lately e-business. He is and was involved in the following international projects: International Business School, Vice Chair, International School FEBA, Chair, International Summer School Mariboros, Chair and EC PHARE/TEMPUS Joint European Project: "Establishing Undergraduate Education Center for Management of Small and Medium Sized Companies at University of Maribor", Co-Chair. He was a visiting professor at the University of Boros, Sweden, and a Fulbright scholar at Boston University, Massachusetts, New York University, New York, and Virginia Polytechnic Institute and State University, Blacksburg, Virginia, USA. He has more than 320 Bibliography units (over 90 international ones), participated in more than 50 national and especially international conferences, published 3 books and contributed 6 chapters in 4 books and chaired 3 national conferences. 
